\title{
A combined Phase I and II open-label study on the immunomodulatory effects of seaweed extract nutrient complex
}

This article was published in the following Dove Press journal:

Biologics Targets \& Therapy

15 February 2011

Number of times this article has been viewed

\section{Stephen P Myers' \\ Joan O'Connor' \\ J Helen Fitton ${ }^{2}$ \\ Lyndon Brooks ${ }^{3}$ \\ Margaret Rolfe ${ }^{3}$ \\ Paul Connellan ${ }^{4}$ \\ Hans Wohlmuth ${ }^{4,5}$ \\ Phil A Cheras' \\ Carol Morris ${ }^{4}$}

'NatMed-Research Unit, Research Cluster for Health and Wellbeing, Southern Cross University, Lismore, NSW, Australia; ${ }^{2}$ Marinova Pty Ltd, Cambridge, TAS, Australia; ${ }^{3}$ Graduate Research College, Southern Cross University, Lismore, NSW, Australia; ${ }^{4}$ Centre for Phytochemistry and Pharmacology, Southern Cross University, Lismore, NSW, Australia; ${ }^{5}$ Medicinal Plant Herbarium, Southern Cross University, Lismore, NSW, Australia
Correspondence: Stephen P Myers NatMed-Research Unit, Research Cluster for Health and Wellbeing, Southern Cross University, Military Road, East Lismore, NSW 2480, Australia

Tel +64266203643

Fax +64 266203307

Email smyers@scu.edu.au
Background: Isolated fucoidans from brown marine algae have been shown to have a range of immune-modulating effects. This exploratory study aimed to determine whether a seaweed nutrient complex containing a blend of extracts from three different species of brown algae plus nutrients is safe to administer and has biological potential as an immune modulator. The study was undertaken as an open-label combined Phase I and II study.

Methods: Participants $(\mathrm{n}=10)$ were randomized to receive the study medication at either a $100 \mathrm{mg}(\mathrm{n}=5)$ or $1000 \mathrm{mg}(\mathrm{n}=5)$ dose over 4 weeks. The primary outcome measurement was in vivo changes in lymphocyte subsets. The secondary outcome measures were ex vivo changes in T-lymphocyte (CD4 and CD8) activation, phagocytosis of granulocytes and monocytes, $\mathrm{T}$ helper 1/T helper 2 cytokines, and serum oxygen radical absorbance capacity.

Results: The preparation was found to be safe over the 4 weeks at both doses tested. There were no clinically relevant changes to blood measurements of hemopoietic, hepatic, or renal function. Immunomodulatory measurements showed no dose response between the two doses. The combined results from the two doses demonstrated a significant increase in cytotoxic $\mathrm{T}$ cell numbers and phagocytic capacity in monocytes, and a significant decrease in levels of the inflammatory cytokine interleukin 6 . A separate analysis of the $100 \mathrm{mg}$ dose $(\mathrm{n}=5)$ alone showed a significant linear component over time $(P<0.05)$ for phagocytosis by both granulocytes and monocytes.

Conclusion: The seaweed nutrient complex was safe to use when taken orally over 4 weeks. The preparation was demonstrated to have potential as an immune modulator, and this bioactivity deserves further exploration.

Keywords: seaweed, fucoidan, immune system, complementary medicine, nutraceutical

\section{Background}

Marine algae have been used by humans as both a food and a medicine for thousands of years. ${ }^{1,2}$ The populations of Japan and Korea consume seaweed or 'macroalgae' every day, with daily consumption averaging $14.2 \mathrm{~g}$ in $\mathrm{Japan}^{3}$ and $6.6 \mathrm{~g}$ in Korea. ${ }^{4}$ A recent epidemiological study in Japan found that dietary seaweed was associated with lowered all-cause mortality and lower mortality from lung cancer for men and women, from pancreatic cancer for men, and from cerebrovascular disease for women. ${ }^{5}$ In pregnant Japanese women, dietary intake of seaweed has been associated with a decreased prevalence of allergic rhinitis. ${ }^{6}$ Although it is not considered a common part of Western diets, people in Western societies regularly ingest alginates and carrageenans derived from macroalgae as a component of foods, and therapeutic macroalgae preparations such as kelp are used as natural mineral supplements, especially 
for their iodine content. ${ }^{1,2}$ Commonly used dietary seaweeds include Undaria pinnatifida (wakame), ${ }^{7}$ Porphyra species (nori), ${ }^{8}$ Laminaria species (kelp, kombu), ${ }^{9}$ Palmaria palmata (dulse), ${ }^{10}$ and Fucus vesiculosus (bladder wrack). ${ }^{11}$

Fucoidans are considered to be one of the main therapeutic components of brown algae ${ }^{12}$ and constitute up to $25 \%-30 \%$ of the algae dry weight, depending on the specific seaweed species and, to a lesser extent, on season variation at time of harvesting. ${ }^{13}$ Structurally, the fucoidans are composed of sulfated homo- and heteropolysaccharides (including polysaccharides with a high content of glucuronic acid and a low content of fucose and sulfates) as well as polysaccharides built as sulfated homopolymers of fucose. ${ }^{13}$ In addition to fucose, they also contain other monosaccharides (eg, mannose, galactose, glucose, xylose), uronic acids, acetyl groups, and protein. ${ }^{12}$ The range of fucoidan structures is extremely diverse, as brown algae synthesize highly branched polysaccharides with species-specific sugar compositions. In addition, every species produces multiple types of fucoidans that can differ in the proportion of monosaccharide moieties. ${ }^{13}$

Brown marine algae in the form of seaweed extracts have been shown in animal studies to have a marked antitumor effect when delivered either intravenously or orally, an effect partly attributed to the stimulation of both innate and specific immunity. ${ }^{14-17}$ Isolated fucoidans from brown algae have been shown to have a range of immune-modulating effects. Ex vivo, Fucus-derived fucoidan had immunostimulating and maturing effects on bone marrow-derived dendritic cells, perhaps via the modulation of nuclear factor-kappa B (NF- $\kappa \mathrm{B}) .{ }^{18}$ In human monocyte-derived dendritic cells, fucoidan increased levels of tumor necrosis factor alpha (TNF- $\alpha$ ), interferon gamma (IFN- $\gamma$ ), and interleukin 12 (IL-12). When naive T cells were stimulated by the fucoidan-treated dendritic cells, they differentiated towards a helper T cell type 1 (Th1). ${ }^{19}$ Fucus-derived fucoidan has been shown to stimulate the enzyme granzyme A, which is believed to induce the production of cytokines in a variety of cells, and may in part explain the immunemodulating mechanism of fucoidans. ${ }^{20}$

In animal studies, intravenously administered Fucusderived fucoidan was observed to have a potent, long-lasting mobilizing effect on hemopoetic stem cells when injected into mice ${ }^{21,22}$ or primates. ${ }^{22}$ These cells replenish the immune cells in tissues and organs. In a mouse model, Cladosiphonderived fucoidan downregulated IL-6 (a Th2 cytokine) and ameliorated colitis. ${ }^{23}$ Other studies in mice have observed immunomodulatory effects chiefly by increasing the activity of natural killer (NK) cells and via a modulation of the Th1:Th2 ratio. ${ }^{24,25}$
In human studies, low levels of serum uptake of fucoidans were observed after ingestion of Undaria fucoidan, determined by using a novel antibody raised against sulfated polysaccharides. ${ }^{26}$ When this fucoidan was ingested over 12 days, it increased the amount of the chemokine stromal cell-derived factor 1 and also the number of chemokine receptor CXCR4-expressing hemopoetic stem cells. The levels of the chemokine IFN- $\gamma$ also increased. ${ }^{27}$

The toxicity of seaweed extracts is generally very low. There were no toxicological changes observed in rats given up to $300 \mathrm{mg} / \mathrm{kg}$ orally of fucoidan from Laminaria japonica. Anticoagulant effects were observed at doses of 900$2500 \mathrm{mg} / \mathrm{kg}$, but no other signs of toxicity were observed. ${ }^{28}$ A polyphenol-rich fraction of Fucus was also shown to lack acute toxic effects in rats after 4 weeks of oral dosing. ${ }^{29}$

We have recently demonstrated that a seaweed nutrition complex (containing a blend of extracts from three different species of brown algae plus nutrients zinc, manganese, and vitamin B6) has marked bioactivity in reducing the symptoms of osteoarthritis of the knee. ${ }^{30}$ To date, the mechanism of action for this effect is unknown. In this study, we examined the effects of the same preparation on the immune function of healthy individuals using an open-label design at two doses to determine immunomodulatory effects. This was a combined Phase I and II study aimed at determining acute safety and efficacy.

\section{Methods}

\section{Research design}

This trial was an exploratory study conducted as an openlabel dosing study, with two different doses randomized to participants, conducted in 2008 over 4 weeks (28 days) in Lismore, a regional city in northern New South Wales (Australia). The study was approved by the Human Research Ethics Committee of Southern Cross University (Ethics approval number: ECN-07-36). The research was conducted in compliance with Good Clinical Practices and in accordance with the guidelines of the Australian National Health and Medical Research Council and the Declaration of Helsinki (as revised in 2004). The trial was registered with the Australian and New Zealand Clinical Trials Register (ACTRN12607000228482).

\section{Participants}

A convenience sample of healthy individuals aged between 18 and 65 years was recruited by email from staff and students at Southern Cross University, and from Lismore and surrounding areas through newspaper advertising, regional 
radio, and television. All participants received a study information sheet outlining the study and signed an informed consent form agreeing to participate.

A sample size of 10 participants was based on data from previous work undertaken at Southern Cross University on the number required in a pilot study to demonstrate changes in immune parameters.

Participants were included if they were healthy, had neither an acute nor a chronic medical condition, and were nonsmokers. Participants were excluded if they were taking antioxidant medications and/or other dietary supplements; had poor venous access; had a history of any autoimmune disorders or diabetes; were taking nonsteroidal anti-inflammatory drugs, immune suppressant drugs, cytokines, interferon, echinacea, or other immune-stimulating herbs; had clinically abnormal liver function tests at baseline; developed a cold or other acute upper respiratory tract infection or influenza during the course of the study; were unwilling to have blood taken three times during the study; or were unwilling to comply with the study protocols.

\section{Outcome measurements}

Safety was assessed by actively monitoring adverse events and by a full blood count, liver function tests, and determination of urea, creatinine, electrolytes, cholesterol, and triglycerides taken at the first baseline measurement and at the conclusion of the study to assess toxicity to the hemopoietic, hepatic, and renal systems. Vital signs (pulse and blood pressure) and weight were also monitored at every measurement point.

The primary efficacy outcome measurements were in vivo changes in lymphocyte subsets (mature T cells [CD3+], B cells [CD19+], helper T cells [CD3+, CD4+], cytotoxic T cells [CD3+, CD8+], and NK cells [CD3-CD16+ and/or $\mathrm{CD} 56+])$. The secondary outcome measures were ex vivo changes in T-lymphocyte (CD4, CD8) activation, phagocytosis by granulocytes and monocytes, $\mathrm{T}$ helper $1 / \mathrm{T}$ helper 2 cytokines (IFN- $\gamma$, TNF- $\alpha$, IL-10, IL-6, IL-4, IL-2), and serum oxygen radical absorbance capacity.

Efficacy measurements were taken at day 1 (baseline), day 3 , and day 28 . Three measurements were taken in total, and participants attended three clinics during which weight, blood pressure, pulse rate, and concomitant medication use were recorded and fasting blood samples collected.

Subjects returned all remaining capsules at each clinic, and these were counted as a measure of compliance. The investigator maintained an inventory record of all capsules received and dispensed. It was assumed that capsules not returned were taken.
Participants were asked at the end of the study to evaluate the study medication by answering a question indicating their satisfaction, dissatisfaction, or neither satisfaction nor dissatisfaction with the study medication.

\section{Study medication and dose}

The study medication used Maritech ${ }^{\circledR}$ extracts (Marinova Pty Ltd, Hobart, Australia), which contains novel fucoidan-rich extracts of seaweeds and which are manufactured using a proprietary aqueous process that produces largely unaltered fucoidan fractions. They are complex 'whole plant' extracts that in addition to a substantial fucoidan concentration also contain significant levels of bioactive seaweed polyphenols (polyphloroglucinols) associated with the fucoidan molecule. In this study, we used a blend of three Maritech ${ }^{\circledR}$ extracts from different species of brown seaweeds: Maritech ${ }^{\circledR}$ Fucus vesiculosis $(85 \% \mathrm{w} / \mathrm{w})$, Maritech ${ }^{\circledR}$ Macrocystis pyrifera $(10 \% \mathrm{w} / \mathrm{w})$, and Maritech ${ }^{\circledR}$ Laminaria japonica $(5 \% \mathrm{w} / \mathrm{w})$. In addition, vitamin B6, zinc sulfate, and manganese sulfate were included in the formulation, as detailed in Table 1. The study medication was manufactured as $100 \mathrm{mg}$ and $250 \mathrm{mg}$ capsules (Gel Caps) under the code of Good Manufacturing Practice. The total fucoidan concentration in the 100 and $250 \mathrm{mg}$ capsules was 75 and $187.5 \mathrm{mg}$, respectively.

Subjects were randomized to either a 100 or $1000 \mathrm{mg}$ dose group using the research randomizer website (www.randomizer.org). Five sets of two numbers per set, using a range of one to two, were generated. These numbers were used to assign the participants to either the 100 or $1000 \mathrm{mg}$ dose. The $100 \mathrm{mg}$ dose was delivered in one $100 \mathrm{mg}$ gel capsule daily (taken in the morning) to five participants. The $1000 \mathrm{mg}$ dose was delivered as four $250 \mathrm{mg}$ capsules daily (two capsules taken twice daily) to five participants. The capsules were selfadministered orally by the participants after food.

\section{Laboratory assays}

\section{Lymphocyte subsets}

Blood was collected in ethylene diamine tetra-acetic acid (EDTA) tubes ( $4 \mathrm{~mL}$ of blood per participant), stored at room temperature, and analyzed within 24 hours of collection.

Table I Contents of Maritech ${ }^{\circledR}$ extract capsules

\begin{tabular}{lll}
\hline Component & $\mathbf{1 0 0 ~} \mathbf{~ g g}$ & $\mathbf{2 5 0} \mathbf{~ m g}$ \\
\hline Maritech ${ }^{\circledR}$ Fucus vesiculosis & $85 \mathrm{mg}$ & $212.5 \mathrm{mg}$ \\
Maritech ${ }^{\circledR}$ Macrocystis pyrifera & $5 \mathrm{mg}$ & $12.5 \mathrm{mg}$ \\
Maritech $^{\circledR}$ Laminaria japonica & $10 \mathrm{mg}$ & $25 \mathrm{mg}$ \\
Pyridoxine hydrochloride & $57.5 \mathrm{mg}$ & $14.38 \mathrm{mg}$ \\
Zinc sulfate monohydrate & $25 \mathrm{mg}$ & $6.25 \mathrm{mg}$ \\
Manganese sulfate & $4 \mathrm{mg}$ & $1 \mathrm{mg}$ \\
\hline
\end{tabular}


Flow cytometric analysis was used for the quantitation of $\mathrm{T}$ cells (including helper and suppressor subsets), B cells, and NK cells. Staining of peripheral blood leukocytes was performed by the lyse/no wash method using MultiTest IMK kit reagents (catalogue no. 340503, Becton Dickinson, San Jose, CA, USA).

Fifty microliters of whole blood (EDTA) was added to $20 \mu \mathrm{L}$ of both fluorochrome-conjugated monoclonal antibodies (anti-CD3fluoresceinisothiocyanate [FITC]/ CD8phycoerythrin [PE]/CD45peridinin chlorophyll protein [PerCP]/CD4allo-phycocyanin [APC] and anti-CD3FITC/ $\mathrm{CD}[16+56] \mathrm{PE} / \mathrm{CD} 45$ PerCP/CD19 APC). Tubes were vortexed and incubated for 15 minutes in the dark at room temperature. Four-hundred and fifty microliters of $1 \times$ MultiTest Lysing Solution was added to each tube, vortexed, and incubated for 15 minutes in the dark at room temperature.

Analysis was carried out on a four-color FACSCalibur Flow Cytometer and MultiSET Software (Becton Dickinson) using excitation wavelengths of 488 and $635 \mathrm{~nm}$.

\section{T cell activation}

Lithium heparinized blood ( $4 \mathrm{~mL}$ per participant) was stored at room temperature and analyzed within 8 hours of collection. Lymphocyte activation was measured on whole blood according to the expression of an early activation marker (CD69) in T cells stimulated with phytohemagglutinin (PHA-M) (Phaseolus vulgaris, Sigma L2646, Sigma-Aldrich, St Louis, MO, USA). This was achieved using FastImmune T-cell Value Bundle II (catalogue no. 340408, Becton Dickinson) and flow cytometry to determine the population of activated $\mathrm{T}$ cells.

In brief, $5 \mu \mathrm{L}$ of $1 \mathrm{mg} / \mathrm{mL}$ PHA-M was added to $495 \mu \mathrm{L}$ of whole blood, vortexed, and incubated for 4 hours at $37^{\circ} \mathrm{C}$ $\left(5 \% \mathrm{CO}_{2}\right)$. Unstimulated controls were run in parallel for each participant. Aliquots $(50 \mu \mathrm{L})$ of preincubated blood were then added to $10 \mu \mathrm{L}$ of fluorochrome-labeled monoclonal antibodies (anti- $\gamma 1 \mathrm{FITC} / \gamma 1 \mathrm{PE} / \mathrm{CD} 3 \mathrm{PerCP}$, anti-CD4FITC/CD69PE/ CD3PerCP, and anti-CD8FITC/CD69PE/CD3PerCP) in three separate tubes. The tubes were mixed and incubated for 15 minutes at room temperature in the dark. Four-hundred and fifty microliters of $1 \times$ FACS Lysing Solution was added to each tube, vortexed, and incubated for 15 minutes in the dark at room temperature.

The percentage of T cells (total T cells, CD4 + T cells, and CD8 + T cells) expressing CD69 was then determined using a four-color FACSCalibur Flow Cytometer and CellQuest Pro Software (Becton Dickinson).

\section{Phagocytosis}

Lithium heparinized blood ( $4 \mathrm{~mL}$ per participant) was stored at room temperature and analyzed within 8 hours of collection. Blood samples were assayed for granulocyte and monocyte phagocytic activity (post E. coli stimulation) by flow cytometry using the Phagotest kit (Orpegen Pharma 10-0100, Heidelberg, Germany).

Aliquots $(100 \mu \mathrm{L})$ of blood were precooled in an ice bath for 10 minutes. Each was spiked with $20 \mu \mathrm{L}$ of FITC-labeled $E$. coli (diluted in saline to equivalent $5 \times 10^{6}$ bacteria), gently vortexed, then incubated at $37^{\circ} \mathrm{C}$, and $0^{\circ} \mathrm{C}$ controls remained on ice. Activity was stopped by placing all tubes on ice simultaneously after 5 minutes of incubation. Cells were quenched (externally), washed, and red cells lysed using the solution provided in the kit. DNA stain solution $(200 \mu \mathrm{L})$ was added to each tube to allow differentiation between free E. coli and human leukocytes.

For each sample, the percentage of phagocytes (granulocytes and monocytes) that had ingested the fluorochromelabeled bacteria (E. coli) was determined using a Becton Dickinson FACSCalibur Flow Cytometer.

\section{Th ITh2 cytokine secretion}

Lithium heparinized blood ( $4 \mathrm{~mL}$ per participant) was stored at room temperature and stimulated within 8 hours of collection. Cytokine secretion of blood, post ex vivo stimulation with PHA-M, was measured in plasma using the human Th1/ Th2 Cytokine (CBA) Kit II (Becton Dickinson, catalogue no. 551809).

In brief, $5 \mu \mathrm{L}$ of $1 \mathrm{mg} / \mathrm{mL}$ PHA-M (Phaseolus vulgaris, Sigma L2646) was added to $495 \mu \mathrm{L}$ of whole blood, vortexed, and incubated for 4 hours at $37^{\circ} \mathrm{C}\left(5 \% \mathrm{CO}_{2}\right)$. Unstimulated controls were run in parallel for each participant, and then vortexed and centrifuged for 5 minutes at $1500 \mathrm{~g}$ (room temperature), plasma was removed, and the samples stored at $-80^{\circ} \mathrm{C}$. Stored plasma samples were thawed, vortexed, and centrifuged ( 5 minutes, $3000 \mathrm{~g}$, room temperature) immediately prior to analysis.

The cytokine profiles (IFN- $\gamma$, TNF- $\alpha$, IL-10, IL-6, IL-4, IL-2) were determined for each sample using the standard CBA Kit protocol, which employs a series of capture beads with discrete fluorescence intensities to detect multiple cytokines in plasma. The samples were analyzed using a four-color FACSCalibur Flow Cytometer and CBA software.

\section{Oxygen radical absorbance capacity (ORAC)}

Clotted blood ( $5 \mathrm{~mL}$ per participant) was centrifuged for 5 minutes at $1500 \mathrm{~g}$, serum removed, and stored at $-80^{\circ} \mathrm{C}$. 
Stored serum samples were thawed, vortexed, and centrifuged for 3 minutes at 10,000 $\mathrm{g}$ at room temperature prior to analysis.

The test sera were pretreated with $0.5 \mathrm{M}$ perchloric acid (Sigma) and centrifuged for 3 minutes at 10,000 $g$ at room temperature. Supernatants from each sample were serially diluted with $75 \mathrm{mM}$ phosphate buffer ( $\mathrm{pH}$ 7.4) (Sigma) to give a dilution series of $1 / 8,1 / 16,1 / 32$, and $1 / 64$. Trolox (vitamin E analog) (Fluka, Buchs, Switzerland) and epicatechin (Sigma) were also diluted and run as a standard and control, respectively, with equivalent final concentrations of perchloric acid. Ten microliters of fluorescein $\left(6.0 \times 10^{-7}\right.$

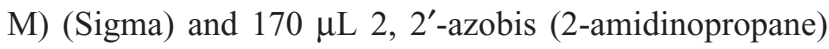
dihydrochloride (AAPH) (Wako, Richmond, VA, USA) were added to each $20 \mu \mathrm{L}$ test sample, Trolox standard, and epicatechin control dilution in a 96-well microplate (Greiner, Frickenhausen, Germany). Fluorescence and blank controls were also run. Hydrophilic ORAC, assessed as the ability to protect fluorescein against AAPH degradation and standardized against Trolox, was measured using a Wallac Victor $^{2}$ plate reader and expressed as Trolox equivalents ( $\mu \mathrm{mol} \mathrm{TE} / \mathrm{L})$.

\section{Statistical methods}

Blood safety measures, which included hematology and blood biochemistry measures, and lipid profile measures were analyzed by repeated-measures analysis with the withinsubject time (day 1, day 28) main effect, the between-subject treatment (100 mg, $1000 \mathrm{mg})$ effect, and time by treatment interaction. The multivariate Wilks' lambda statistic was used to assess the significance of effects involving time (main effect and interaction), and the treatment effect main effect was assessed with the univariate $F$ test.

Repeated-measures analysis of variance was conducted over the three measurement times (day 1, day 3, and day 28) for all immune function measures, including serum ORAC, and the model included the within-subject (repeated) time effect (day 1, day 3, day 28), the between-subject treatment main effect (100 mg, $1000 \mathrm{mg}$ ), and the time by treatment interaction. The multivariate Wilks' lambda statistic was used to assess the significance of effects involving time (main effect and interaction) and the treatment effect main effect was assessed with the univariate $F$ test. When any significant effects were present, Bonferroni-adjusted pairwise multiple comparisons were conducted to determine significant differences. In the case of significant multivariate time effects, decomposition into the linear and quadratic time components was also considered with treatments combined and/or treated separately. Where the linear decomposition occurred, univariate time effects when the sphericity assumption held were also presented. Treatments were considered separately if it appeared that either one of the treatments may have indicated a beneficial effect (all means increasing or decreasing).

SPSS version 15 was used for all analyses, and the significance level was set to $P=0.05$; however, as this was a pilot study, significance tests that resulted in $P<0.1$ have also been highlighted.

\section{Results Study participants}

The study screened 15 volunteers and subsequently enrolled 10 people who met the inclusion/exclusion criteria. All 10 participants completed the study and comprised nine females (mean age $[ \pm \mathrm{SD}] 33.4$ years $[ \pm 9.36])$ and one male (age 45 years). Five participants received the formulation in doses of $100 \mathrm{mg}$, and five received $1000 \mathrm{mg}$. There was a 95\% compliance with participants taking $1000 \mathrm{mg}$ daily, and $97.14 \%$ compliance in individuals taking $100 \mathrm{mg}$ per day. The study medication was well tolerated, as all 10 participants evaluated their experience of taking the study medication as neither satisfied nor dissatisfied (they did not notice benefits or adverse effects).

The mean $( \pm \mathrm{SD})$ ages (years) of 33.6 (10.78) and 31.4 (9.58) for the 100 and $1000 \mathrm{mg}$ arms, respectively, were not statistically different. Baseline means, standard deviations, minima and maxima for blood pressures, weight, and pulse rate for participants in each of the two study arms are reported in Table 2 .

Only systolic blood pressure $(P=0.009)$ differed at baseline between the two treatments, with the $100 \mathrm{mg}$ treatment

Table 2 Baseline blood pressure, weight, pulse rate: means $( \pm S D)$ minima and maxima by treatment arm

\begin{tabular}{|c|c|c|c|c|c|c|c|c|c|c|}
\hline \multirow[t]{2}{*}{ Baseline } & \multicolumn{5}{|c|}{$100 \mathrm{mg}$} & \multicolumn{5}{|c|}{$1000 \mathrm{mg}$} \\
\hline & $\mathbf{N}$ & Mean & SD & Min & Max & $\mathbf{N}$ & Mean & SD & Min & Max \\
\hline BPS (mmHg) & 5 & 124.60 & 4.56 & 118 & 129 & 5 & 113.00 & 6.00 & 104 & 120 \\
\hline BPD (mmHg) & 5 & 74.80 & 9.42 & 62 & 87 & 5 & 72.00 & 5.15 & 67 & 80 \\
\hline Weight (kg) & 5 & 65.40 & 9.61 & 53 & 75 & 5 & 67.400 & 9.50 & 57 & 81 \\
\hline Pulse rate (per min) & 5 & 71.60 & 14.79 & 56 & 94 & 5 & 60.00 & 9.70 & 48 & 70 \\
\hline
\end{tabular}

Abbreviations: BPD, diastolic blood pressure; BPS, systolic blood pressure; max, maximum; min, minimum; SD, standard deviation. 
group having an average systolic blood pressure mean of $124.6( \pm 4.56) \mathrm{mmHg}$ significantly higher than the $1000 \mathrm{mg}$ treatment group mean $113( \pm 6.00) \mathrm{mmHg}$.

\section{Safety}

The reports of adverse events were mild and self-limiting; however, the two participants who experienced an adverse event (hay fever $n=1$; head cold $n=1$ ) took one dose of Ibuprofen (a nonsteroidal anti-inflammatory agent) on the last day of the fourth week of the study. The adverse events occurred in the last 2 days of the study and were not considered to be related to the medication.

The descriptive statistics for blood safety measures (full blood count, liver function tests, and determination of urea, creatinine, electrolytes, cholesterol, and triglycerides) on days 1 and 28 are presented in Tables 3 and 4. The results of the repeated-measures analysis of variance using two measurement times (day 1 and day 28) with $P$-values for the time, treatment, and time by treatment effects are outlined in Tables 5 and 6 . The only significant effect in these analyses was a significant treatment effect for potassium $(P=0.035)$, but the change was small and well within the clinical reference range so was assessed as not of clinical significance. Interestingly, the outcome measure for the cholesterol ratio showed near-significant beneficial change over time $(P<0.10)$.

\section{Immune function}

The descriptive statistics for the lymphocyte subsets, phagocytic activity of monocytes and granulocytes, and cytokines on days 1, 3, and 28 are presented in Table 7. Only granulocyte levels $(P=0.025)$ differed at baseline between the two treatments, with the $100 \mathrm{mg}$ treatment group having significantly lower mean levels $(50.9 \% \pm 4.43 \%)$ than the $1000 \mathrm{mg}$ treatment group $(59.87 \% \pm 5.73 \%)$.

The results of the repeated-measures analysis of variance conducted over the three measurement points (day 1, day 3 , and day 28$)$ as the significance values ( $P$-values) of the effects of time, time by treatment interaction, and treatment main effect for each of the immune function outcome measures are presented in Table 8 . Only day 3 and day 28 measurements for IL-4 were used in the repeated-measures analysis of variance due to the absence of variation at day 1 (all scores were zero).

None of the time by treatment effects was significant $(P>0.05)$, nor was any treatment main effect significant. However, the outcome measures of B cells (CD19), cytotoxic T cells, monocyte phagocytosis, and IL-6 showed a significant change over time $(P<0.05)$. Granulocyte phagocytosis demonstrated a significant increase over time $(P=0.038)$ and a near-significant difference between treatments averaged over time $(P=0.06)$. T cells, activation of $\mathrm{CD} 4$, activation of CD8, NK cells, and IL-2 showed near-significant changes over time $(P<0.1)$. IFN- $\gamma$ and TNF- $\alpha$, as well as granulocyte phagocytosis, showed near-significant changes $(P<0.1)$ between treatments averaged over time.

Estimated time means (combined over treatments) and results of Bonferroni-adjusted pairwise comparisons for the significant time responses of B cells (CD19), cytotoxic $\mathrm{T}$ cells, monocyte phagocytosis, and IL-6 are reported in Table 9 , and time by treatment means are graphically represented in Figure 1. For these immune function outcomes, the significant time effect always resulted in a significant difference between days 1 and 28. B cells and IL-6 decreased significantly over time ( $P=0.003, P=0.011$, respectively), cytotoxic T cells increased (day 3 ) then decreased to day 28 , and monocytes increased significantly from day 1 to day 28 $(P=0.002)$. A common pattern can be observed across several measures (eg, NK cells for $100 \mathrm{mg}$ in Table 7) in which there is an increase to day 3 and a decrease by day 28 , echoing the data for cytotoxic $\mathrm{T}$ cells.

Estimated means for granulocyte phagocytosis by each treatment by time and combined treatment by time, as well as treatment averaged over time (combined), are presented together with the results of the Bonferroni-adjusted pairwise comparisons over time in Table 10 with graphical representations in Figure 2. There was a significant multivariate time effect $(P=0.038)$ with a near-significant univariate time effect $(P=0.070)$, which decomposed into a significant linear time contrast $(P=0.008)$ and a nonsignificant quadratic contrast $(P=0.759)$ for the treatments when considered together. Post hoc tests were consistent with this linear trend, with day 28 being significantly higher than day $1(P=0.025)$. When the two treatments were analyzed separately, the multivariate and univariate time effects were nonsignificant for each of the treatments $(P=0.125$ and $P=0.147$, respectively, for $100 \mathrm{mg}$, and $P=0.164$ and $P=0.288$, respectively, for $1000 \mathrm{mg}$ ), but there was a significant linear contrast for the $100 \mathrm{mg}$ treatment $(P=0.038)$ and a nonsignificant linear contrast for the $1000 \mathrm{mg}$ treatment $(P=0.146)$. In considering the near-significant treatment effect (the difference between treatments), the $100 \mathrm{mg}$ treatment mean was lower (not significantly, $P=0.06$ ) than $1000 \mathrm{mg}$.

As the data suggested that phagocytosis by monocytes and granulocytes and IL- 6 behaved in a beneficial manner with the $100 \mathrm{mg}$ treatment, separate repeated-measures analyses were performed on these immune response variables 
Table 3 Blood safety: means, SD, minima, and maxima by treatment arm and measurement occasion

\begin{tabular}{|c|c|c|c|c|c|c|c|c|c|c|}
\hline \multirow[t]{2}{*}{ Measure } & \multicolumn{5}{|c|}{$100 \mathrm{mg}$} & \multicolumn{5}{|c|}{$1000 \mathrm{mg}$} \\
\hline & $\mathbf{N}$ & Mean & SD & Min & $\operatorname{Max}$ & $\mathbf{N}$ & Mean & SD & Min & Max \\
\hline \multicolumn{11}{|l|}{ Hematology day I } \\
\hline Red cell count $\left(\times 10^{12} / \mathrm{L}\right)$ & 5 & 4.5 & 0.2 & 4.3 & 4.9 & 5 & 4.3 & 0.3 & 4.0 & 4.7 \\
\hline Hemoglobin (g/L) & 5 & 138.2 & 6.7 & 129.0 & 147.0 & 5 & 133.6 & 9.0 & 123.0 & 143.0 \\
\hline Hematocrit (\%) & 5 & 0.41 & 0.02 & 0.39 & 0.44 & 5 & 0.40 & 0.02 & 0.37 & 0.42 \\
\hline Mean corpuscular volume (fL) & 5 & 92.0 & 2.9 & 89.0 & 96.0 & 5 & 91.8 & 1.9 & 90.0 & 95.0 \\
\hline White cell count $\left(\times 10^{9} / L\right)$ & 5 & 6.1 & 1.7 & 4.6 & 8.9 & 5 & 6.1 & 0.5 & 5.5 & 6.9 \\
\hline Lymphocytes $\left(\times 10^{9} / \mathrm{L}\right)$ & 5 & 2.2 & 0.3 & 2.0 & 2.6 & 5 & 1.9 & 0.3 & 1.7 & 2.4 \\
\hline Monocytes $\left(\times 10^{9} / \mathrm{L}\right)$ & 5 & 0.4 & 0.1 & 0.3 & 0.5 & 5 & 0.5 & 0.2 & 0.3 & 0.8 \\
\hline Neutrophils (×109/L) & 5 & 3.4 & 1.5 & 2.2 & 5.9 & 5 & 3.4 & 0.4 & 3.0 & 4.0 \\
\hline Basophils $\left(\times 10^{9} / \mathrm{L}\right)$ & 5 & 0.0 & 0.1 & 0.0 & 0.1 & 5 & 0.0 & 0.0 & 0.0 & 0.0 \\
\hline Eosinophils $\left(\times 10^{9} / \mathrm{L}\right)$ & 5 & 0.1 & 0.1 & 0.1 & 0.3 & 5 & 0.2 & 0.1 & 0.1 & 0.4 \\
\hline Platelets $\left(\times 10^{9} / \mathrm{L}\right)$ & 5 & 300.0 & 22.6 & 277.0 & 337.0 & 5 & 287.4 & 79.3 & 199.0 & 369.0 \\
\hline \multicolumn{11}{|l|}{ Biochemistry day I } \\
\hline Alkaline phosphatase $(\mu / L)$ & 5 & 54.2 & 11.2 & 41.0 & 64.0 & 5 & 57.0 & 9.8 & 44.0 & 69.0 \\
\hline Serum alanine aminotransferase $(\mu / L)$ & 5 & 12.8 & 3.1 & 10.0 & 18.0 & 5 & 13.4 & 4.5 & 8.0 & 20.0 \\
\hline Aspartate aminotransferase $(\mu / L)$ & 5 & 19.0 & 3.8 & 15.0 & 25.0 & 5 & 18.6 & 2.4 & 16.0 & 21.0 \\
\hline Gamma glutamyl transferase $(\mu / L)$ & 5 & 14.8 & 5.4 & 9.0 & 23.0 & 5 & 13.6 & 2.1 & 12.0 & 17.0 \\
\hline Bilirubin $(\mu \mathrm{mol} / \mathrm{L})$ & 5 & 10.8 & 2.8 & 7.0 & 14.0 & 5 & 10.8 & 3.0 & 6.0 & 14.0 \\
\hline Protein (g/L) & 5 & 67.4 & 3.4 & 64.0 & 72.0 & 5 & 69.0 & 2.9 & 66.0 & 73.0 \\
\hline Albumin $(g / L)$ & 5 & 44.6 & 2.3 & 42.0 & 48.0 & 5 & 44.0 & 2.8 & 41.0 & 47.0 \\
\hline Sodium (mmol/L) & 5 & 138.6 & 1.3 & 137.0 & 140.0 & 5 & 138.8 & 0.4 & 138.0 & 139.0 \\
\hline Potassium (mmol/L) & 5 & 3.7 & 0.1 & 3.6 & 3.9 & 5 & 4.1 & 0.4 & 3.7 & 4.7 \\
\hline Chloride (mmol/L) & 5 & 106.4 & 1.3 & 105.0 & 108.0 & 5 & 106.0 & 1.6 & 104.0 & 108.0 \\
\hline BUN/urea (mmol/L) & 5 & 3.9 & 1.1 & 2.7 & 5.2 & 5 & 4.0 & I.I & 2.7 & 5.8 \\
\hline Creatinine (mmol/L) & 5 & 71.0 & 7.5 & 64.0 & 80.0 & 5 & 77.0 & 11.7 & 66.0 & 97.0 \\
\hline \multicolumn{11}{|l|}{ Hematology day 28} \\
\hline Red cell count $\left(\times 10^{12} / \mathrm{L}\right)$ & 5 & 4.3 & 0.3 & 3.8 & 4.6 & 5 & 4.2 & 0.4 & 3.6 & 4.5 \\
\hline Hemoglobin $(g / L)$ & 5 & 136.0 & 10.2 & 118.0 & 143.0 & 5 & 131.8 & 10.9 & 114.0 & 141.0 \\
\hline Hematocrit (\%) & 5 & 0.40 & 0.03 & 0.35 & 0.42 & 5 & 0.39 & 0.03 & 0.34 & 0.41 \\
\hline Mean corpuscular volume (fL) & 5 & 92.0 & 2.3 & 90.0 & 95.0 & 5 & 92.0 & 1.9 & 90.0 & 95.0 \\
\hline White cell count $\left(\times 10^{9} / L\right)$ & 5 & 5.9 & 0.9 & 4.9 & 7.1 & 5 & 5.7 & 1.1 & 4.0 & 7.0 \\
\hline Lymphocytes (×10\%/L) & 5 & 2.1 & 0.3 & 1.7 & 2.6 & 5 & 2.0 & 0.3 & 1.8 & 2.4 \\
\hline Monocytes $\left(\times 10^{9} / \mathrm{L}\right)$ & 5 & 0.4 & 0.1 & 0.3 & 0.5 & 5 & 0.6 & 0.1 & 0.5 & 0.8 \\
\hline Neutrophils $\left(\times 10^{9} / \mathrm{L}\right)$ & 5 & 3.1 & 0.9 & 2.3 & 4.6 & 5 & 3.4 & 0.8 & 2.3 & 4.3 \\
\hline Basophils $\left(\times 10^{9} / \mathrm{L}\right)$ & 5 & 0.0 & 0.1 & 0.0 & 0.1 & 5 & 0.0 & 0.0 & 0.0 & 0.0 \\
\hline Eosinophils $\left(\times 10^{9} / \mathrm{L}\right)$ & 5 & 0.2 & 0.1 & 0.1 & 0.4 & 5 & 0.2 & 0.1 & 0.0 & 0.3 \\
\hline Platelets $\left(\times 10^{9} / \mathrm{L}\right)$ & 5 & 296.3 & 31.1 & 271.0 & 337.0 & 5 & 278.8 & 59.2 & 206.0 & 351.0 \\
\hline \multicolumn{11}{|l|}{ Biochemistry day 28} \\
\hline Alkaline phosphatase $(\mu / L)$ & 5 & 58.6 & 10.7 & 47.0 & 69.0 & 5 & 60.8 & 6.8 & 52.0 & 71.0 \\
\hline Serum alanine aminotransferase $(\mu / L)$ & 5 & 17.4 & 3.0 & 13.0 & 21.0 & 5 & 25.6 & 18.8 & 10.0 & 58.0 \\
\hline Aspartate aminotransferase $(\mu / L)$ & 5 & 21.8 & 4.4 & 17.0 & 29.0 & 5 & 25.0 & 7.3 & 17.0 & 37.0 \\
\hline Gamma glutamyl transferase $(\mu / L)$ & 5 & 13.4 & 4.3 & 9.0 & 20.0 & 5 & 14.6 & 5.7 & 10.0 & 24.0 \\
\hline Bilirubin $(\mu \mathrm{mol} / \mathrm{L})$ & 5 & 11.4 & 4.2 & 7.0 & 17.0 & 5 & 12.6 & 5.3 & 5.0 & 18.0 \\
\hline Protein $(g / L)$ & 5 & 67.4 & 3.9 & 64.0 & 73.0 & 5 & 68.2 & 3.0 & 64.0 & 71.0 \\
\hline Albumin (g/L) & 5 & 44.8 & 2.7 & 43.0 & 49.0 & 5 & 43.6 & 2.6 & 41.0 & 47.0 \\
\hline Sodium (mmol/L) & 5 & 139.4 & 0.9 & 138.0 & 140.0 & 5 & 139.0 & 1.0 & 138.0 & 140.0 \\
\hline Potassium (mmol/L) & 5 & 4.0 & 0.2 & 3.7 & 4.2 & 5 & 4.2 & 0.3 & 3.9 & 4.6 \\
\hline Chloride (mmol/L) & 5 & 107.4 & 1.8 & 105.0 & 110.0 & 5 & 106.0 & 1.2 & 105.0 & 108.0 \\
\hline BUN/urea (mmol/L) & 5 & 4.0 & 0.3 & 3.8 & 4.5 & 5 & 5.0 & 1.7 & 2.5 & 6.4 \\
\hline Creatine (mmol/L) & 5 & 68.6 & 8.5 & 60.0 & 82.0 & 5 & 78.6 & 18.9 & 64.0 & 111.0 \\
\hline
\end{tabular}

Abbreviations: BUN, blood urea nitrogen; max, maximum; min, minimum; SD, standard deviation. 
Table 4 Lipid profile (mmol/L): means, SD, minima, and maxima by treatment arm and measurement occasion

\begin{tabular}{|c|c|c|c|c|c|c|c|c|c|c|c|}
\hline & \multirow[t]{2}{*}{ Day } & \multicolumn{5}{|c|}{$100 \mathrm{mg}$} & \multicolumn{5}{|c|}{$1000 \mathrm{mg}$} \\
\hline & & $\mathbf{N}$ & Mean & SD & Min & $\operatorname{Max}$ & $\mathbf{N}$ & Mean & SD & Min & Max \\
\hline \multirow[t]{2}{*}{ Cholesterol } & 1 & 5 & 4.88 & 0.98 & 3.40 & 5.70 & 5 & 3.94 & 0.38 & 3.40 & 4.30 \\
\hline & 28 & 5 & 4.74 & 0.74 & 3.70 & 5.50 & 5 & 3.92 & 0.81 & 3.10 & 5.10 \\
\hline \multirow[t]{2}{*}{ HDL } & 1 & 5 & 1.45 & 0.36 & 1.14 & 1.94 & 5 & 1.18 & 0.21 & 0.94 & 1.48 \\
\hline & 28 & 5 & 1.51 & 0.35 & 1.25 & 1.99 & 5 & 1.25 & 0.39 & 0.84 & 1.83 \\
\hline \multirow[t]{2}{*}{ LDL } & 1 & 5 & 3.04 & 0.88 & 1.90 & 4.10 & 5 & 2.34 & 0.29 & 2.00 & 2.70 \\
\hline & 28 & 5 & 2.84 & 0.66 & 2.30 & 3.70 & 5 & 2.26 & 0.43 & 1.90 & 2.90 \\
\hline \multirow[t]{2}{*}{ Ratio cholesterol:HDL } & 1 & 5 & 3.46 & 0.84 & 2.70 & 4.70 & 5 & 3.40 & 0.38 & 2.80 & 3.80 \\
\hline & 28 & 5 & 3.22 & 0.70 & 2.30 & 4.20 & 5 & 3.24 & 0.40 & 2.80 & 3.90 \\
\hline \multirow[t]{2}{*}{ Triglycerides } & I & 5 & 0.90 & 0.34 & 0.50 & 1.40 & 5 & 0.90 & 0.34 & 0.50 & 1.40 \\
\hline & 28 & 5 & 0.86 & 0.37 & 0.40 & $\mathrm{I} .40$ & 5 & 0.84 & 0.29 & 0.40 & 1.10 \\
\hline
\end{tabular}

Abbreviations: HDL, high-density lipoprotein; LDH, low-density lipoprotein; max, maximum; min, minimum; SD, standard deviation.

using the $100 \mathrm{mg}$ treatment only $(\mathrm{n}=5)$. The multivariate Wilks lambda significance and the univariate significance were used as an indication of significant time effects, and the significance of the decomposition of the univariate time effect into a linear component was used as an indication of the existence of a beneficial effect of the $100 \mathrm{mg}$ treatment over time. Only phagocytosis by granulocytes and monocytes showed a significant linear component in a

Table 5 Blood safety measure: $P$-values for repeated measures analysis of variance

\begin{tabular}{|c|c|c|c|}
\hline Measure & Time & $\begin{array}{l}\text { Time by } \\
\text { treatment }\end{array}$ & Treatment \\
\hline Red cell count $\left(\times 10^{12} / \mathrm{L}\right)$ & 0.079 & 0.897 & $0.44 I$ \\
\hline Hemoglobin $(g / L)$ & 0.309 & 0.916 & 0.445 \\
\hline Hematocrit (\%) & 0.172 & 0.772 & 0.307 \\
\hline $\begin{array}{l}\text { Mean corpuscular } \\
\text { volume (fL) }\end{array}$ & 0.608 & 0.608 & 0.946 \\
\hline White cell count $\left(\times 10^{9} / L\right)$ & 0.419 & 0.846 & 0.873 \\
\hline Lymphocytes $\left(\times 10^{9} / \mathrm{L}\right)$ & 0.767 & 0.557 & 0.319 \\
\hline Monocytes $\left(\times 10^{9} / \mathrm{L}\right)$ & 0.276 & 0.367 & 0.054 \\
\hline Neutrophils $\left(\times 10^{9} / \mathrm{L}\right)$ & 0.567 & 0.506 & 0.764 \\
\hline Eosinophils $\left(\times 10^{9} / \mathrm{L}\right)$ & 1.000 & 0.373 & 0.788 \\
\hline Platelets $\left(\times 10^{9} / \mathrm{L}\right)$ & 0.442 & $0.74 I$ & 0.698 \\
\hline Alkaline phosphatase $(\mu / L)$ & 0.065 & 0.880 & 0.683 \\
\hline $\begin{array}{l}\text { Serum alanine } \\
\text { aminotransferase }(\mu / L)\end{array}$ & 0.089 & 0.407 & 0.359 \\
\hline $\begin{array}{l}\text { Aspartate } \\
\text { aminotransferase }(\mu / L)\end{array}$ & 0.065 & 0.428 & 0.537 \\
\hline $\begin{array}{l}\text { Gamma glutamyl } \\
\text { transferase }(\mu / L)\end{array}$ & 0.825 & 0.207 & 1.000 \\
\hline Bilirubin $(\mu \mathrm{mol} / \mathrm{L})$ & 0.175 & 0.478 & 0.806 \\
\hline Protein $(g / L)$ & 0.591 & 0.591 & 0.564 \\
\hline Albumin (g/L) & 0.870 & 0.626 & 0.576 \\
\hline Sodium (mmol/L) & 0.187 & 0.412 & 0.849 \\
\hline Potassium (mmol/L) & 0.170 & 0.220 & 0.035 \\
\hline Chloride (mmol/L) & 0.368 & 0.368 & 0.291 \\
\hline BUN/urea (mmol/L) & 0.227 & 0.302 & 0.429 \\
\hline Creatinine $(\mathrm{mmol} / \mathrm{L})$ & 0.847 & 0.347 & 0.306 \\
\hline
\end{tabular}

Abbreviation: BUN, blood urea nitrogen. beneficial direction over time $(P=0.038$ and $P=0.014$, respectively).

Estimated means, standard errors, and 95\% confidence intervals for the immune responses of monocytes, granulocytes, and IL-6 for the $100 \mathrm{mg}$ treatment, together with the significance values for the Wilks lambda test for the time effect, the univariate test for time, and the linear component over time, are presented in Table 11. Phagocytosis of granulocytes and monocytes for the $100 \mathrm{mg}$ treatment over time are also shown in Figure 3.

\section{Serum ORAC}

The descriptive statistics for serum ORAC on days 1, 3, and 28 are presented in Table 12. The results of the repeatedmeasures analysis of variance showed that serum ORAC significantly increased over time $(P=0.003)$, but the time by treatment effect and the treatment main effect were nonsignificant $(P>0.05)$. Estimated time means and the results of Bonferroni-adjusted pairwise comparisons are presented in Table 13, with time by treatment means illustrated in Figure 4.

\section{Discussion}

This study investigated the acute safety and immunomodulatory effects of a seaweed nutrient complex containing a blend

Table 6 Cholesterol and triglycerides: P-values for repeated measures analysis of variance

\begin{tabular}{llll}
\hline Outcome & Time & Time by treatment & Treatment \\
\hline Cholesterol & 0.627 & 0.714 & 0.089 \\
HDL & 0.158 & 0.946 & 0.230 \\
LDL & 0.403 & 0.715 & 0.105 \\
Ratio cholesterol:HDL & 0.087 & 0.707 & 0.959 \\
Triglycerides & 0.561 & 0.906 & 0.961 \\
\hline
\end{tabular}

Abbreviations: HDL, high-density lipoprotein; LDH, low-density lipoprotein. 
Table 7 Immune function means, SD, minima, and maxima by treatment arm and measurement occasion

\begin{tabular}{|c|c|c|c|c|c|c|c|c|c|c|c|}
\hline \multirow[t]{2}{*}{ Outcome } & \multirow[t]{2}{*}{ Day } & \multicolumn{5}{|c|}{$100 \mathrm{mg}$} & \multicolumn{5}{|c|}{$1000 \mathrm{mg}$} \\
\hline & & $\mathbf{N}$ & Mean & SD & Min & Max & $\mathbf{N}$ & Mean & SD & Min & Max \\
\hline \multirow[t]{3}{*}{$\mathrm{T}$ cells } & I & 5 & 2.01 & 0.32 & 1.77 & 2.55 & 5 & 1.93 & 0.45 & 1.58 & 2.55 \\
\hline & 3 & 5 & 2.19 & 0.36 & 1.83 & 2.73 & 5 & 1.96 & 0.35 & 1.45 & 2.31 \\
\hline & 28 & 5 & 1.93 & 0.35 & 1.63 & 2.49 & 5 & 1.90 & 0.40 & $\mathrm{I} .47$ & 2.49 \\
\hline \multirow[t]{3}{*}{ B cells CDI9 } & I & 5 & 0.24 & 0.08 & 0.18 & 0.38 & 5 & 0.25 & 0.08 & 0.16 & 0.38 \\
\hline & 3 & 5 & 0.24 & 0.09 & 0.13 & 0.33 & 5 & 0.23 & 0.06 & 0.17 & 0.33 \\
\hline & 28 & 5 & 0.18 & 0.08 & 0.10 & 0.31 & 5 & 0.20 & 0.06 & 0.16 & 0.31 \\
\hline \multirow[t]{3}{*}{ Helper T cells } & I & 5 & 1.30 & 0.19 & 0.99 & $\mathrm{I} .46$ & 5 & 1.28 & 0.25 & 0.92 & 1.57 \\
\hline & 3 & 5 & 1.44 & 0.43 & 0.88 & 1.93 & 5 & 1.30 & 0.20 & 1.02 & 1.54 \\
\hline & 28 & 5 & 1.28 & 0.24 & 0.86 & $1.4 \mid$ & 5 & 1.28 & 0.18 & 0.97 & 1.41 \\
\hline \multirow[t]{3}{*}{ Cytotoxic T cells } & I & 5 & $0.7 \mathrm{I}$ & 0.33 & 0.41 & 1.19 & 5 & 0.66 & 0.31 & 0.41 & 1.19 \\
\hline & 3 & 5 & 0.76 & 0.26 & 0.45 & 1.10 & 5 & 0.71 & 0.24 & 0.45 & 1.10 \\
\hline & 28 & 5 & 0.66 & 0.28 & 0.41 & 1.11 & 5 & 0.65 & 0.28 & 0.41 & 1.11 \\
\hline \multirow[t]{3}{*}{ Natural killer cells } & I & 5 & 0.28 & 0.10 & 0.16 & 0.39 & 5 & 0.24 & 0.11 & 0.06 & 0.33 \\
\hline & 3 & 5 & 0.40 & 0.18 & 0.19 & 0.67 & 5 & 0.35 & 0.21 & 0.08 & 0.67 \\
\hline & 28 & 5 & 0.26 & 0.06 & 0.20 & 0.33 & 5 & 0.24 & 0.09 & 0.08 & 0.32 \\
\hline \multirow[t]{3}{*}{ Total T cells } & I & 5 & 32.32 & 9.19 & 18.80 & 42.30 & 5 & 30.76 & 5.27 & 24.20 & 38.70 \\
\hline & 3 & 5 & 28.96 & 9.41 & 17.10 & 40.60 & 5 & 29.04 & 8.51 & 20.50 & 41.10 \\
\hline & 28 & 5 & 34.56 & 10.47 & 16.70 & 44.00 & 5 & 33.56 & 6.19 & 28.30 & 44.00 \\
\hline \multirow[t]{3}{*}{ Activation CD4 } & $\mathrm{I}$ & 5 & 30.16 & 9.11 & 17.10 & 40.30 & 5 & 26.06 & 6.01 & 17.70 & 34.50 \\
\hline & 3 & 5 & 27.00 & 9.38 & 15.20 & 38.70 & 5 & 24.64 & 8.84 & 15.00 & 38.70 \\
\hline & 28 & 5 & 31.34 & 9.77 & 15.40 & 40.50 & 5 & 30.30 & 6.36 & 23.10 & 40.50 \\
\hline \multirow[t]{3}{*}{ Activation CD8 } & I & 5 & 35.48 & 11.38 & 18.30 & 46.40 & 5 & 35.68 & 4.51 & 30.40 & 41.60 \\
\hline & 3 & 5 & 29.08 & 11.37 & 14.80 & 42.70 & 5 & 31.22 & 9.17 & 20.10 & 40.40 \\
\hline & 28 & 5 & 39.42 & 13.53 & 16.20 & 51.60 & 5 & 36.56 & 9.07 & 29.50 & 51.60 \\
\hline Granulocyte & I & 5 & 50.92 & 4.43 & 44.7I & 55.62 & 5 & 59.87 & 5.73 & 49.83 & 64.38 \\
\hline \multirow[t]{2}{*}{ Phagocytosis } & 3 & 5 & 52.46 & 8.27 & 41.64 & 63.16 & 5 & 63.15 & 9.27 & 47.18 & 69.11 \\
\hline & 28 & 5 & 55.85 & 7.66 & 45.13 & 65.10 & 5 & 62.52 & 4.71 & 55.75 & 67.76 \\
\hline Monocyte & I & 5 & 37.79 & 5.57 & 31.02 & 44.58 & 5 & 45.53 & 6.98 & 36.35 & 53.08 \\
\hline \multirow[t]{2}{*}{ Phagocytosis } & 3 & 5 & 42.74 & 6.73 & 33.52 & 50.91 & 5 & 48.27 & 4.64 & 40.00 & 50.93 \\
\hline & 28 & 5 & 50.40 & 7.18 & 41.05 & 59.97 & 5 & 51.99 & 4.76 & 45.02 & 56.96 \\
\hline \multirow[t]{3}{*}{ IFN-gamma } & 1 & 5 & 9862 & 8943 & 0 & 19,094 & 5 & 1412 & 898 & 292 & 2490 \\
\hline & 3 & 5 & 8302 & 6829 & 0 & 15,336 & 5 & $|64|$ & 623 & 732 & 2239 \\
\hline & 28 & 5 & 7327 & 7247 & 0 & 15,336 & 5 & 1258 & 574 & 314 & 1777 \\
\hline \multirow[t]{3}{*}{ IL-6 } & I & 5 & 20,955 & 5388 & $|7,54|$ & 30,374 & 5 & 23,509 & 6858 & 15,476 & 31,678 \\
\hline & 3 & 5 & 22,108 & 6696 & 15,476 & 33,042 & 5 & 24,195 & 4894 & 20,105 & 32,695 \\
\hline & 28 & 5 & 16,022 & $518 \mid$ & 10,955 & 22,957 & 5 & 18,864 & 5073 & 13,805 & 27,079 \\
\hline \multirow[t]{3}{*}{ TNF-alpha } & I & 5 & 3282 & 1041 & 1832 & 4343 & 5 & 2564 & 1214 & 919 & 4242 \\
\hline & 3 & 5 & 6150 & 3413 & 1832 & $|1,22|$ & 5 & 2186 & 1380 & 742 & 4067 \\
\hline & 28 & 5 & 4337 & 1998 & 1409 & 6433 & 5 & 4435 & 1245 & 2924 & 6373 \\
\hline \multirow[t]{3}{*}{ IL-10 } & I & 5 & 40.40 & 21.10 & 18.00 & 66.00 & 5 & 41.20 & 8.47 & 28.00 & 49.00 \\
\hline & 3 & 5 & 47.80 & 17.54 & 28.00 & 73.00 & 5 & 49.00 & 35.43 & 18.00 & 105.00 \\
\hline & 28 & 5 & 29.20 & 20.56 & 0.00 & 57.00 & 5 & 29.80 & 23.69 & 0.00 & 64.00 \\
\hline IL-2 & I & 5 & 25.80 & 15.35 & 0.00 & 41.00 & 5 & 20.20 & 11.45 & 0.00 & 28.00 \\
\hline & 3 & 5 & 28.00 & 3.74 & 22.00 & 32.00 & 5 & 27.40 & 9.48 & 16.00 & 41.00 \\
\hline & 28 & 5 & 20.00 & 19.39 & 0.00 & 52.00 & 5 & 15.20 & 10.80 & 0.00 & 30.00 \\
\hline IL-4 & I & 5 & 0.00 & 0.00 & 0.00 & 0.00 & 5 & 0.00 & 0.00 & 0.00 & 0.00 \\
\hline & 3 & 5 & 20.60 & 29.00 & 0.00 & 61.00 & 5 & 8.00 & 17.89 & 0.00 & 40.00 \\
\hline & 28 & 5 & 11.40 & 25.49 & 0.00 & 57.00 & 5 & 14.40 & 13.16 & 0.00 & 25.00 \\
\hline
\end{tabular}

Abbreviations: IFN, interferon; IL, interleukin; max, maximum; min, minimum; SD, standard deviation; TNF, tumor necrosis factor. 
Table 8 Immune function outcomes: $P$-values for repeated measures analysis of variance

\begin{tabular}{llll}
\hline $\begin{array}{l}\text { Immune function } \\
\text { outcome }\end{array}$ & Time & $\begin{array}{l}\text { Time } \\
\text { by treatment }\end{array}$ & Treatment \\
\hline T cells & 0.077 & 0.409 & 0.609 \\
B cells CDI9 & 0.003 & 0.486 & 0.900 \\
Helper T cells & 0.440 & 0.576 & 0.727 \\
Cytotoxic T cells & 0.018 & 0.498 & 0.837 \\
Natural killer cells & 0.098 & 0.896 & 0.667 \\
Total T cells & 0.127 & 0.853 & 0.871 \\
Activation CD4 & 0.052 & 0.313 & 0.631 \\
Activation CD8 & 0.068 & 0.703 & 0.977 \\
Granulocyte & 0.038 & 0.496 & 0.060 \\
phagocytosis & & & \\
Monocyte & 0.005 & 0.320 & 0.168 \\
Phagocytosis & & & \\
IFN-gamma & 0.490 & 0.379 & 0.059 \\
IL-6 & 0.004 & 0.955 & 0.477 \\
TNF-alpha & 0.203 & 0.117 & 0.087 \\
IL-4 & 0.901 & 0.495 & 0.605 \\
IL-I0 & 0.227 & 0.999 & 0.935 \\
IL-2 & 0.077 & 0.699 & 0.569 \\
\hline Abbreviation IN $~$ & &
\end{tabular}

Abbreviations: IFN, interferon; IL, interleukin; TNF, tumor necrosis factor.

of extracts from three brown algae species (Fucus vesiculosis, Macrocystis pyrifera, and Laminaria japonica) plus vitamin B6, zinc, and manganese. The preparation was demonstrated to be safe over the course of the study. Adverse events experienced during the study were mild and self-limiting; there were no changes in hemopoetic, hepatic, or renal functions or in cholesterol and triglycerides of clinical significance; and the vital signs of participants remained healthy. This follows a study using the same preparation in 12 individuals with osteoarthritis over 12 weeks, which also demonstrated acute safety of the preparation. ${ }^{30}$

This study did not show a dose response effect in the efficacy outcomes between the two doses of the study preparation (100 $\mathrm{mg}$ and $1000 \mathrm{mg}$ ), as no discernible differences in any immune measure or the serum ORAC were found in the primary analysis. This may be explained by one of two possibilities. Firstly, the maximum effect was reached by the $100 \mathrm{mg}$ dose, and no further response was possible at higher doses. Secondly, the study was not powered to discern such differences, which is a type II error. Given the small study numbers, it is more likely to be a type II error, and a larger study needs to be undertaken to determine dose responsiveness. Trends worthy of pursuit in a larger study include near-significant changes $(P<0.1)$ between treatments averaged over time, which were found for IFN- $\gamma$, TNF- $\alpha$, and phagocytosis by granulocytes.

The study did find significant time effects, suggesting that the combined results from both doses showed significant change over time for B cells (CD19), cytotoxic T cells, phagocytosis by monocytes, and IL-6. Comparisons for the significant time response showed that, between day 1 and day 28 , B cells and IL-6 decreased significantly, phagocytosis by monocytes increased significantly, and cytotoxic $\mathrm{T}$ cells increased then decreased to day 28. Total $\mathrm{T}$ cells, activation CD4, activation CD8, NK cells, and IL-2 showed a nearsignificant change over time $(P<0.1)$.

The separate repeated-measures analyses on phagocytosis by monocytes, phagocytosis by granulocytes, and IL-6 using only the $100 \mathrm{mg}$ treatment demonstrated that phagocytosis

Table 9 Estimated time means and multiple comparison results for B cells (CDI9), cytotoxic T cells, monocyte phagocytosis, and IL-6

\begin{tabular}{|c|c|c|c|c|c|c|}
\hline & Day & Mean & SD & Lower $95 \%$ & Upper 95\% & Multiple comparisons \\
\hline$B$ cells & 1 & 0.244 & 0.026 & 0.183 & 0.305 & $I$ versus $28 P=0.003$ \\
\hline \multirow[t]{2}{*}{ (CDI9) } & 3 & 0.236 & 0.024 & 0.180 & 0.292 & 3 versus $28 P=0.069$ \\
\hline & 28 & 0.193 & 0.023 & 0.140 & 0.246 & \\
\hline \multirow[t]{3}{*}{ Cytotoxic T cells } & 1 & 0.686 & 0.102 & 0.451 & 0.921 & $I$ versus $28 P=0.018$ \\
\hline & 3 & 0.736 & 0.079 & 0.553 & 0.919 & 3 versus $28 P=0.024$ \\
\hline & 28 & 0.653 & 0.089 & 0.448 & 0.858 & $I$ versus $3 P=0.032$ \\
\hline \multirow[t]{3}{*}{ Monocyte phagocytosis } & 1 & $41.66 I$ & 1.996 & 37.058 & 46.264 & $I$ versus $28 P=0.002$ \\
\hline & 3 & 45.506 & 1.828 & 41.290 & 49.722 & 3 versus $28 P=0.031$ \\
\hline & 28 & 51.194 & 1.927 & 46.751 & 55.637 & \\
\hline \multirow[t]{3}{*}{ IL-6 } & 1 & 22,232 & 1950 & 17,735 & 26,729 & I versus $28 P=0.011$ \\
\hline & 3 & 23,152 & 1854 & 18,875 & 27,428 & 3 versus $28 P=0.003$ \\
\hline & 28 & 17,443 & 1621 & 13,703 & 21,182 & \\
\hline
\end{tabular}

Abbreviations: IL, interleukin; SD, standard deviation. 
A

B cells

$\left.\begin{array}{r}0.35 \\ 0.30 \\ 0.25 \\ 0 \\ 0.20 \\ \stackrel{0}{5} \\ 0.15 \\ 0.10 \\ 0.05 \\ 0.00\end{array}\right]$

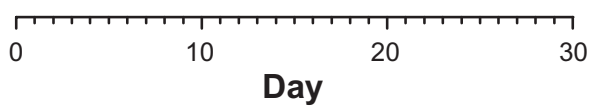

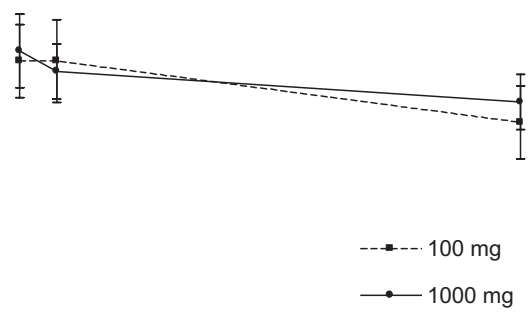

C

Monocyte phagocytosis

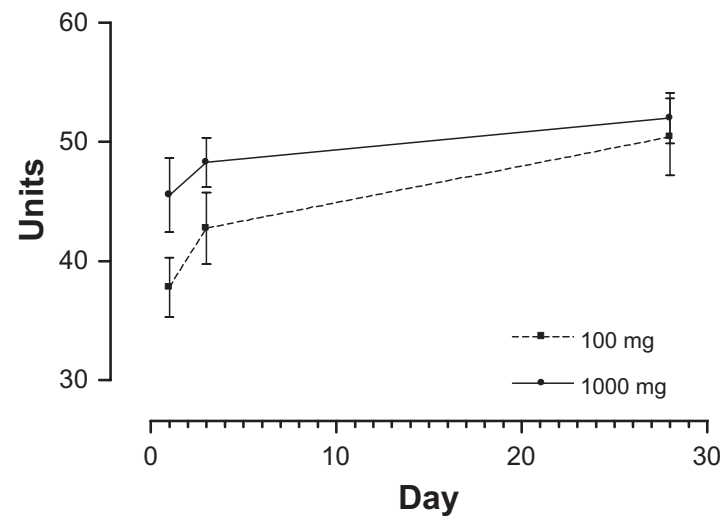

B

Cytotoxic T cells

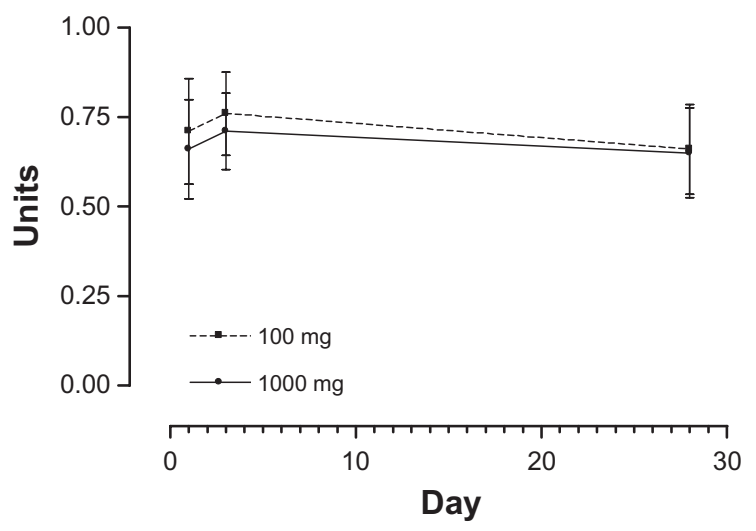

D

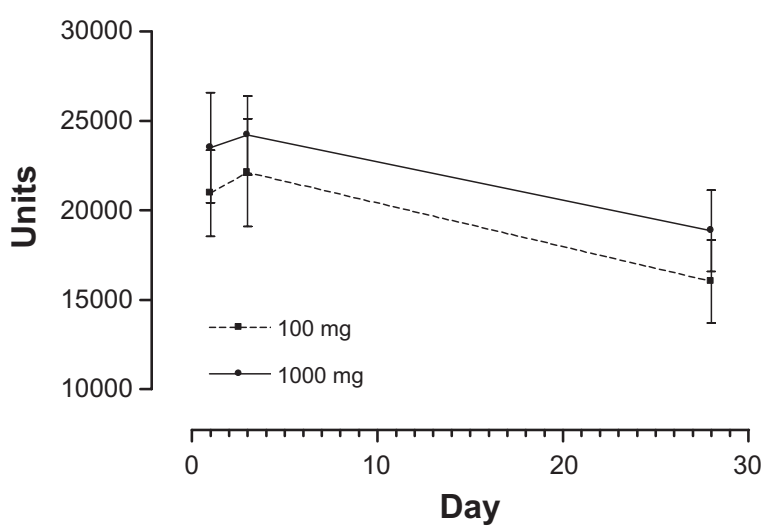

Figure I Mean by treatment over time for B cells (CDI9) (A), cytotoxic T cells (B), monocyte phagocytosis (C), and interleukin-6 (D).

by both granulocytes and monocytes showed a significant linear component.

Serum ORAC similarly did not show a dose response effect between the two treatments but did demonstrate a significant time effect between day 1 and day 3 with the two treatments combined. This represented a $25 \%$ increase in serum ORAC by day 3, which is consistent with other natural antioxidants such as vitamin $\mathrm{C}$ and spinach. ${ }^{31}$ It has been suggested that sulfated polysaccharides from edible seaweeds could be used as natural antioxidants in the food

Table 10 Estimated time and treatment means for granulocyte phagocytosis

\begin{tabular}{|c|c|c|c|c|c|c|}
\hline Treatment & Day & Mean & SD & Lower 95\% & Upper 95\% & Comparisons \\
\hline \multirow[t]{3}{*}{100 mg } & 1 & 50.92 & 2.29 & 45.64 & 56.21 & \\
\hline & 3 & 52.46 & 3.93 & 43.40 & 61.52 & \\
\hline & 28 & 55.85 & 2.85 & 49.29 & 62.41 & \\
\hline \multirow[t]{3}{*}{1000 mg } & 1 & 59.87 & 2.29 & 54.59 & 65.15 & \\
\hline & 3 & 63.15 & 3.93 & 54.09 & 72.21 & \\
\hline & 28 & 62.52 & 2.85 & 55.96 & 69.08 & \\
\hline \multirow[t]{3}{*}{ Combined } & 1 & 55.38 & 1.62 & 51.66 & 59.13 & $I$ versus $3 P=0.563$ \\
\hline & 3 & 57.80 & 2.78 & 51.40 & 64.21 & $I$ versus $28 P=0.025$ \\
\hline & 28 & 59.19 & 2.01 & 54.55 & 63.83 & \\
\hline 100 mg & Combined & 53.08 & 2.84 & 46.54 & 59.62 & $P=0.060$ \\
\hline 1000 mg & Combined & 61.85 & 2.84 & 55.31 & 68.39 & \\
\hline
\end{tabular}

Abbreviation: SD, standard deviation. 


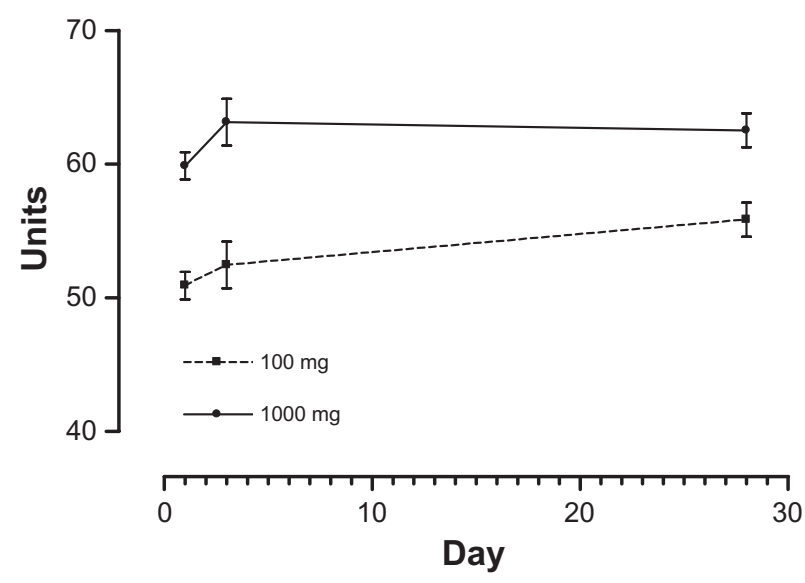

Figure $\mathbf{2}$ Mean by treatment over time for granulocyte phagocytosis.

industry. ${ }^{11}$ The antioxidant effects of manganese in the blend should also be considered as a contributor to this increased activity. However, the pattern of the results showed that the $1000 \mathrm{mg}$ dose continued to increase in activity, whereas the $100 \mathrm{mg}$ dose started to decline. Given that the level of manganese (and B6 and zinc) was the same for both doses, this suggests that seaweed constituents are responsible for at least part of the effect. This role of seaweed as an antioxidant is worth exploring in further research.

Defense against invasive pathogens and the elimination of defective cells are coordinated between the innate and adaptive (specific) immune systems. The nonspecific innate immune system attacks pathogens quickly. This response includes NK cells and phagocytic cells. After a pathogen or defective cell is 'recognized', this response is backed by antigen-specific cells such as cytotoxic T cells. NK cells help to contain viral infections, and a lack of NK cells, either intrinsic or stress induced, is associated with vulnerability to viral infections. ${ }^{32}$ In this study, data at day 3 indicated significant increases in cytotoxic T cells and near-significant increases in NK cells. This short-term increase in cytotoxic T cells was accompanied by a continual increase in phagocytosis by monocytes and the near-significant increase in phagocytosis by granulocytes over the 28-day period. Monocytes and granulocytes are a critical part of the immune system and are responsible for the phagocytosis and destruction of foreign bodies such as bacteria. ${ }^{31}$ Overall, these data suggest an immune-priming role of the nutrient seaweed complex, which is worthy of further exploration. The significant linear component over time for phagocytosis by both monocytes and granulocytes when the $100 \mathrm{mg}$ data were analyzed alone confirms that this dosage has an immunomodulatory effect.

In addition to immune modulation, the complex has potential anti-inflammatory activity, exhibited by the significant decrease in IL-6 between day 1 and day 28 . It is important to note that the measurement taken in this study was not of absolute serum levels of IL-6, which remains to be elucidated, but the amount of IL- 6 produced by challenged cells. IL-6 is a multifunctional cytokine that is produced by many cell types, including leukocytes and endothelial cells. Levels of IL-6 were associated with increased cardiovascular risk in the Women's Health Study. ${ }^{33,34}$ The levels of IL-6 were increased in women with cardiovascular events, and women with median levels of total cholesterol had increased risk if they had high levels of IL-6. This potential anti-inflammatory effect deserves further investigation, as any agent capable of reducing IL-6 may confer substantive health benefits.

Serum antioxidant capacity increased significantly over the course of the study. Long-term increases in serum antioxidant status are correlated with improved health and with lower levels of IL- $6,{ }^{33}$ consistent with this study. The marked effect this preparation demonstrated in osteoarthritis ${ }^{30}$ with the $1000 \mathrm{mg}$ dose reducing the symptoms by $52 \%$, which

Table I I Estimated time means and significance of component effects for $100 \mathrm{mg}$ treatment on specific immune responses

\begin{tabular}{|c|c|c|c|c|c|c|c|c|}
\hline Immune response & Day & Mean & SD & Lower $95 \%$ & Upper $95 \%$ & $\begin{array}{l}\text { Multivariate } \\
\text { Wilks lambda } \\
P\end{array}$ & $\begin{array}{l}\text { Univariate } \\
\text { time } \\
P\end{array}$ & $\begin{array}{l}\text { Linear } \\
\text { component } \\
P\end{array}$ \\
\hline \multirow[t]{3}{*}{ Monocyte phagocytosis } & 1 & 37.79 & 2.49 & 30.87 & 44.71 & 0.068 & 0.006 & 0.014 \\
\hline & 3 & 42.74 & 3.01 & 34.38 & 51.10 & & & \\
\hline & 28 & 50.40 & 3.21 & 41.48 & 59.31 & & & \\
\hline \multirow[t]{3}{*}{ Granulocyte phagocytosis } & 1 & 50.92 & 1.98 & 45.42 & 56.42 & 0.125 & 0.147 & 0.038 \\
\hline & 3 & 52.46 & 3.70 & 42.19 & 62.72 & & & \\
\hline & 28 & 55.85 & 3.43 & 46.333 & 65.37 & & & \\
\hline \multirow[t]{3}{*}{ Production IL-6 } & 1 & $20,955.0$ & 2409.7 & $14,264.6$ & $27,645.4$ & 0.177 & 0.032 & 0.061 \\
\hline & 3 & $22,108.0$ & 2994.5 & |3,794.| & $30,421.9$ & & & \\
\hline & 28 & $16,021.6$ & 2317.0 & 9588.6 & $22,454.6$ & & & \\
\hline
\end{tabular}

Abbreviations: IL, interleukin; SD, standard deviation. 

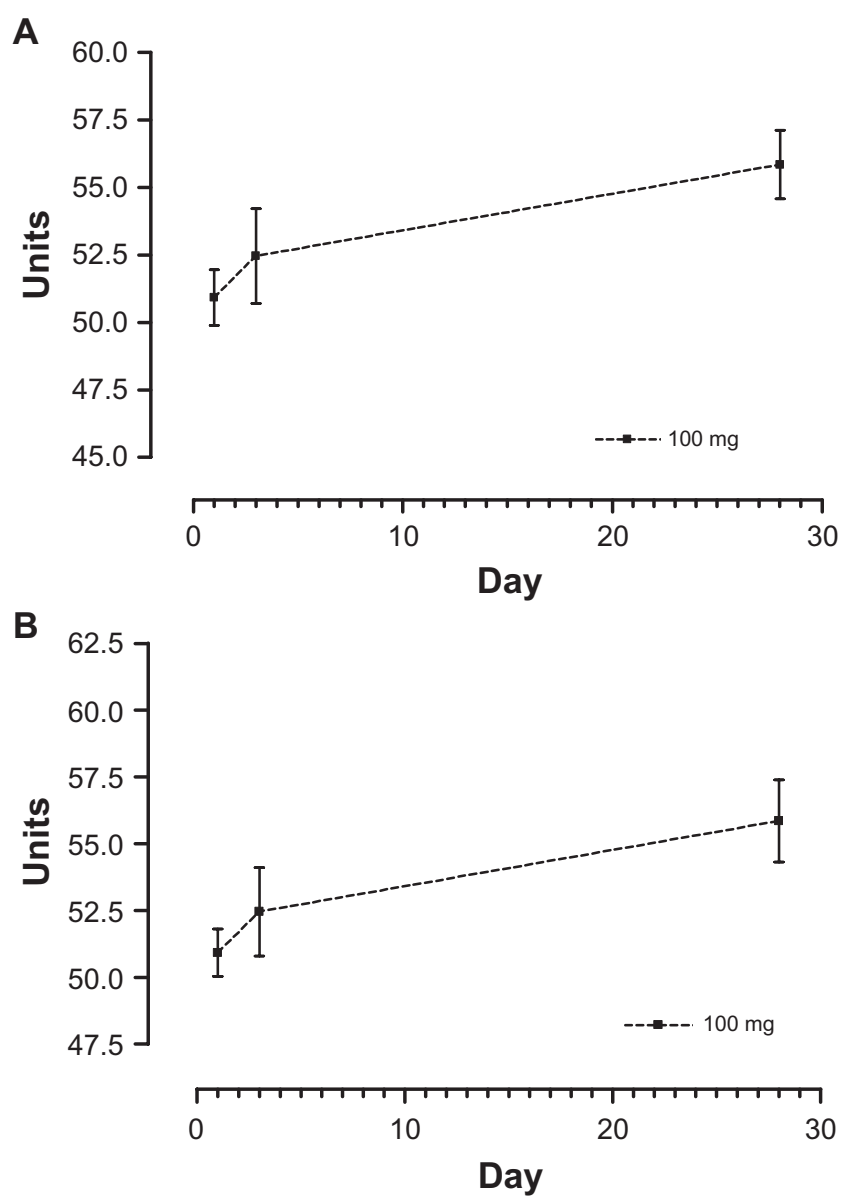

Figure 3 Means over time for $100 \mathrm{mg}$ treatment for phagocytosis by monocytes (A) and granulocytes (B).

is equivalent to the effect expected from a nonsteroidal anti-inflammatory drug, ${ }^{35}$ coupled with the effect on IL-6 and serum antioxidant capacity, provides consistent evidence of anti-inflammatory activity.

The outcome measure for the cholesterol ratio showed near-significant beneficial change over time $(P<0.10)$, which may reflect potential pharmacological activity. A number of seaweed species ${ }^{29-32}$ have been found to have hypolipidemic effects, which may well deserve further study.

The role of the added nutrients in the preparation cannot be assessed independently, and the amount they contributed to the effects of the preparation is unknown. Adequate intake of micronutrients is required for the immune system to function efficiently, ${ }^{36,37}$ and specific nutrients were added to the complex to ensure their availability. Zinc is known to play a role in the immune system; however, its precise roles and mechanisms have not yet been resolved. ${ }^{38}$ Vitamin B6 deficiency is known to depress both humoral and cell-mediated immune responses. ${ }^{39} \mathrm{~A}$ dose of $50 \mathrm{mg}$ daily, equivalent to this study, significantly increased T-lymphocyte and T-helper cell numbers and the percentage of T-suppressor cells in 14 days in a group of critically ill intensive care patients ${ }^{40}$ who were likely to have some degree of immunocompromise. Although we did not see these changes in this study, it is likely that the participants had adequate vitamin B6 intake, given that substantially increased doses of vitamin B6 do not produce added benefits. ${ }^{39}$

A limitation of the study design was that the $100 \mathrm{mg}$ dose was delivered once per day as a single capsule (in the morning), and the $1000 \mathrm{mg}$ dose was delivered twice per day (two $250 \mathrm{mg}$ capsules morning and night, four capsules total per day). Differences in the number of capsules and the dosing schedule between the groups may have had a bearing on the observed outcomes. Other areas of potential bias include gender and diet. Participants in this study comprised nine females and one male, placing an emphasis on the potential effects of female physiology, which may not be generalizable to male physiology. The participants' background diets need to be assessed, as they may vary widely in the intake of seaweed products and land-based fruits and vegetables, which may have an effect on serum ORAC and other laboratory parameters. Further rigorous study needs to eliminate these areas of potential bias.

One shortcoming of seaweed extract and fucoidan research to date has been the lack of data from clinical settings and in vivo models, especially at clinically viable dosage levels. The methods used to prepare extracts of fucoidan from seaweed vary from laboratory preparations to commercial extraction methods, where heat and ethanol may be used during extraction and possibly solvent precipitation. The differences in extraction methods may result in inconsistent biological activity. Lowering the molecular

Table 12 Serum ORAC ( $\mu$ mol Trolox equivalents/L): means, SD, minima, and maxima by treatment arm and measurement occasion

\begin{tabular}{|c|c|c|c|c|c|c|c|c|c|c|c|}
\hline \multirow[t]{2}{*}{ Outcome } & \multirow[t]{2}{*}{ Day } & \multicolumn{5}{|c|}{$100 \mathrm{mg}$} & \multicolumn{5}{|c|}{$1000 \mathrm{mg}$} \\
\hline & & $\mathbf{N}$ & Mean & SD & Min & Max & $\mathbf{N}$ & Mean & SD & Min & Max \\
\hline \multirow[t]{3}{*}{ Serum ORAC } & I & 5 & 612.40 & 92.65 & 483 & 730 & 5 & 697.20 & 64.59 & 635 & 805 \\
\hline & 3 & 5 & 802.60 & 134.05 & 575 & 907 & 5 & 836.20 & 115.25 & 725 & $\mathrm{I}, 01 \mathrm{I}$ \\
\hline & 28 & 5 & 764.40 & 253.28 & 575 & 1,208 & 5 & 890.40 & | 32.29 & 746 & 1,025 \\
\hline
\end{tabular}

Abbreviations: max, maximum; min, minimum; ORAC, oxygen radical absorbance capacity; SD, standard deviation. 
Table 13 Estimated time means and multiple comparison results for serum ORAC

\begin{tabular}{llllll}
\hline Day & Mean & SE & Lower 95\% & Upper 95\% & Multiple comparisons \\
\hline $\mathrm{I}$ & 654.8 & 25.255 & 596.563 & 713.037 & I versus 3 $P=0.003$ \\
3 & 819.4 & 39.529 & 728.246 & 910.554 & I versus $28 P=0.107$ \\
28 & 827.4 & 63.894 & 680.060 & 974.740 & \\
\hline
\end{tabular}

Abbreviations: ORAC, oxygen radical absorbance capacity; SD, standard error.

size of fucoidans by more extensive chemical processing has been shown to inactivate in vivo enzyme inhibitory activity against phospholipase-A2. ${ }^{41}$ For this reason, it has been postulated that the novel aqueous extraction process used in the development of this study medication, which produces largely unaltered fucoidan fractions, may be more clinically effective. Further research is necessary to determine the best method for delivering therapeutic benefits from seaweeds.

This study was an exploratory study, and it is important that it is not over-interpreted. The most significant limitation was that it was an open-label combined Phase I and II trial and therefore was subject to potential bias, which would be reduced by the use of randomization and blinding. This study aimed to explore the potential bioactivity of the preparation on immune function and determine a safe and effective dose that can be used in a more rigorous clinical trial design. This study achieved these aims and demonstrated that the study medication at $100 \mathrm{mg}$ has the potential to act as an immunomodulator.

\section{Conclusion}

A complex containing a blend of seaweed extracts and nutrients when taken orally over 4 weeks was demonstrated to be safe to use over the study period at the doses tested. The

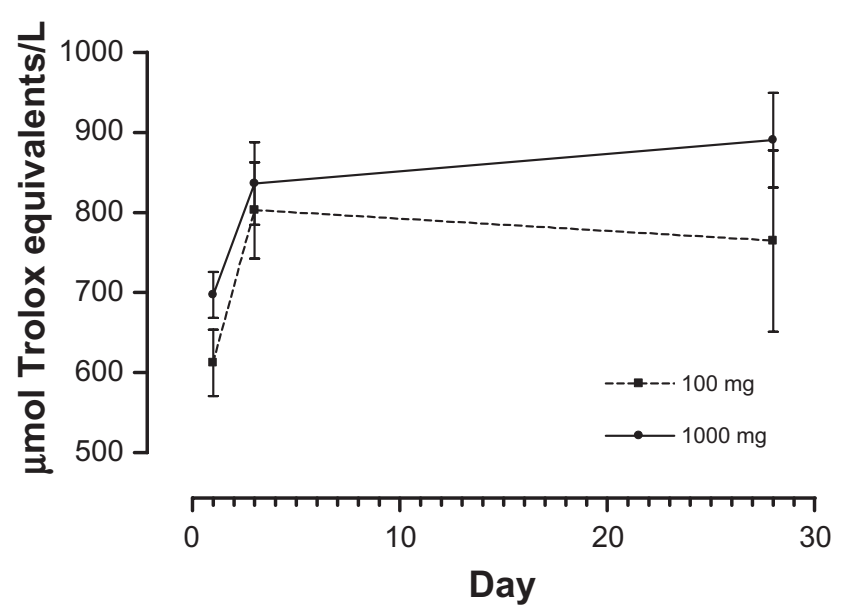

Figure 4 Mean plots by treatment over time for serum ORAC ( $\mu$ mol Trolox equivalents/L).

Abbreviation: ORAC, oxygen radical absorbance capacity.
$100 \mathrm{mg}$ dose was shown to be immunomodulatory, and this pharmacological activity now needs to be demonstrated in a Phase III randomized controlled trial with an appropriate sample size.

\section{Authors' contributions}

SPM was the principal investigator and was involved in the study design, management of the clinical trial, interpretation of the results, and preparation of the manuscript. JO was the study coordinator; was involved in the study design, day-to-day management of the clinical trial, and data entry; and contributed to the manuscript. JHF was involved in study design and interpretation of results and contributed to the manuscript. LB supervised the statistical analysis, was involved in the interpretation of the results, and contributed to the manuscript. MR undertook the statistical analysis, was involved in interpretation of the results, and contributed to the manuscript. PC undertook the immune function studies, was involved in interpretation of the results, and contributed to the manuscript. HW provided botanical expertise and contributed to the manuscript. PAC provided natural products expertise and contributed to the manuscript. $\mathrm{CM}$ directs the laboratory where the immune studies and serum ORAC were undertaken and contributed to the manuscript.

\section{Acknowledgments}

We thank Catherine Avila and Airdre Grant (NatMedResearch), who provided clinical research assistance; Dion Thompson (Centre for Phytochemistry and Pharmacology), who undertook the antioxidant testing; the Northern Rivers Pathology Unit, who undertook the safety measurements; and the participants who made it possible.

\section{Trial registration}

Australian and New Zealand Clinical Trials Register: ACTRN12607000228482.

\section{Disclosure}

The study was sponsored by Marinova Pty Ltd under contract to Southern Cross University and performed independently 
by NatMed-Research. Dr Fitton is employed by Marinova Pty Ltd. Although she was involved in the study design, interpretation of results, and preparation of the manuscript, she had no interaction with any study participant, nor was she involved in the day-to-day running or management of the clinical trial. Marinova Pty Ltd paid the article-processing charge associated with the publication of this paper.

\section{References}

1. Aaronson S. Algae. In: Kiple K, Ornela K, editors. The Cambridge World History of Food. Cambridge, UK: Cambridge University Press; 2000;231-249.

2. Grieve M. A Modern Herbal. Middlesex, England: Penguin Books Ltd;1977.

3. Fukuda S, Saito H, Nakaji S, et al. Pattern of dietary fiber intake among the Japanese general population. Eur J Clin Nutr. 2007;61(1): 99-103.

4. Kim S, Moon S, Popkin BM. The nutrition transition in South Korea. Am J Clin Nutr. 2000;71:44-53.

5. Iso H, Kubota Y. Nutrition and disease in the Japan Collaborative Cohort Study for Evaluation of Cancer (JACC). Asian Pac J Cancer Prev. 2007;8 Suppl:35-80.

6. Miyake Y, Sasaki S, Ohya Y, et al. Dietary intake of seaweed and minerals and prevalence of allergic rhinitis in Japanese pregnant females: baseline data from the Osaka Maternal and Child Health Study. Ann Epidemiol. 2006;16(8):614-621.

7. Yamada Y, Miyoshi T, Tanada S, Imaki M. Digestibility and energy availability of Wakame (Undaria pinnatifida) seaweed in Japanese. Nippon Eiseigaku Zasshi. 1991;46(3):788-794.

8. Bocanegra A, Nieto A, Blas B, Sánchez-Muniz FJ. Diets containing a high percentage of Nori or Konbu algae are well-accepted and efficiently utilised by growing rats but induce different degrees of histological changes in the liver and bowel. Food Chem Toxicol. 2003;41(11): 1473-1480.

9. Teas J. The dietary intake of Laminaria, a brown seaweed, and breast cancer prevention. Nutr Cancer. 1983;4(3):217-222.

10. Galland-Irmouli AV, Fleurence J, Lamghari R, et al. Nutritional value of proteins from edible seaweed Palmaria palmata (dulse). JNutr Biochem. 1999;10(6):353-359.

11. Rupérez P, Ahrazem O, Leal JA. Potential antioxidant capacity of sulfated polysaccharides from the edible marine brown seaweed Fucus vesiculosus. J Agric Food Chem. 2002;50(4):840-845.

12. Li B, Lu F, Wei X, Zhao R. Fucoidan: structure and bioactivity. Molecules. 2008;13(8):1671-1695.

13. Kusaykin M, Bakunina I, Sova V, et al. Structure, biological activity, and enzymatic transformation of fucoidans from the brown seaweeds. Biotechnol J. 2008;3(7):904-915.

14. Funahashi H, Imai T, Mase T, et al. Seaweed prevents breast cancer? Jpn J Cancer Res. 2001;92(5):483-487.

15. Furusawa E, Furusawa S. Effect of pretazettine and viva-natural, a dietary seaweed extract, on spontaneous AKR leukemia in comparison with standard drugs. Oncology. 1988;45(3):180-186.

16. Furusawa E, Furusawa S, Chou SC. Antileukemic activity of VivaNatural, a dietary seaweed extract, on Rauscher murine leukemia in comparison with anti-HIV agents, azidothymidine, dextran sulfate and pentosan polysulfate. Cancer Letters. 1991;56(3):197-205.

17. Yamamoto I, Maruyama H, Takahashi M, Komiyama K. The effect of dietary or intraperitoneally injected seaweed preparations on the growth of sarcoma-180 cells subcutaneously implanted into mice. Cancer Letters. 1986;30(2):125-131.

18. Kim MH, Joo HG. Immunostimulatory effects of fucoidan on bone marrow-derived dendritic cells. Immunol Lett. 2008;115(2): $138-143$
19. Yang M, Ma C, Sun J, et al. Fucoidan stimulation induces a functional maturation of human monocyte-derived dendritic cells. Int Immunopharmacol. 2008;8(13-14):1754-1760.

20. Hirayasu H, Yoshikawa Y, Tsuzuki S, Fushiki T. Sulfated polysaccharides derived from dietary seaweeds increase the esterase activity of a lymphocyte tryptase, granzyme A. J Nutr Sci Vitaminol (Tokyo). 2005;51(6):475-477.

21. Frenette PS, Weiss L. Sulfated glycans induce rapid hematopoietic progenitor cell mobilization: evidence for selectin-dependent and independent mechanisms. Blood. 2000;96(7):2460-2468.

22. Sweeney EA, Lortat-Jacob H, Priestley GV, Nakamoto B, Papayannopoulou T. Sulfated polysaccharides increase plasma levels of SDF-1 in monkeys and mice: involvement in mobilization of stem/progenitor cells. Blood. 2002;99(1):44-51.

23. Matsumoto S, Nagaoka M, Hara T, Kimura-Takagi I, Mistuyama K, Ueyama S. Fucoidan derived from Cladosiphon okamuranus Tokida ameliorates murine chronic colitis through the down-regulation of interleukin-6 production on colonic epithelial cells. Clin Exp Immunol. 2004;136(3):432-439.

24. Maruyama H, Tamauchi H, Hashimoto M, Nakano T. Suppression of Th2 immune responses by Mekabu fucoidan from Undaria pinnatifida sporophylls. Int Arch Allergy Immunol. 2005;137(4): 289-294.

25. Maruyama H, Tamauchi H, lizuka M, Nakano T. The role of NK cells in antitumor activity of dietary fucoidan from Undaria pinnatifida sporophylls (Mekabu). Planta Med. 2006;72(15):1415-1417.

26. Irhimeh MR, Fitton JH, Lowenthal RM, Kongtawelert P. A quantitative method to detect fucoidan in human plasma using a novel antibody. Methods Find Exp Clin Pharmacol. 2005;27(10):705-710.

27. Irhimeh MR, Fitton JH, Lowenthal RM. Fucoidan ingestion increases the expression of CXCR4 on human CD34+ cells. Exp Hematol. 2007;35(6):989-994.

28. Li N, Zhang Q, Song J. Toxicological evaluation of fucoidan extracted from Laminaria japonica in wistar rats. Food Chem Toxicol. $2005 ; 43: 421-426$.

29. Zaragozá MC, López D, P Sáiz M, et al. Toxicity and antioxidant activity in vitro and in vivo of two Fucus vesiculosus extracts. J Agric Food Chem. 2008;56(17):7773-7780.

30. Myers SP, O'Connor J, Fitton JH, et al. A combined phase I and II open label study on the effects of a seaweed extract nutrient complex on osteoarthritis. Biologics. 2010;4:33-44.

31. Serbina NV, Jia T, Hohl TM, Pamer EG. Monocyte-mediated defense against microbial pathogens. Annu Rev Immunol. 2008;26: 421-452.

32. Ashcraft KA, Bonneau RH. Psychological stress exacerbates primary vaginal herpes simplex virus type $1(\mathrm{HSV}-1)$ infection by impairing both innate and adaptive immune responses. Brain Behav Immun. 2008;22(8):1231-1240

33. Walston J, Xue Q, Semba RD, et al. Serum antioxidants, inflammation, and total mortality in older women. Am J Epidemiol. 2006;163(1):18-26.

34. Ridker PM, Hennekens CH, Buring JE, Rifai N. C-reactive protein and other markers of inflammation in the prediction of cardiovascular disease in women. $N$ Engl J Med. 2000;342(12):836-843.

35. Ong CK, Lirk P, Tan CH, Seymour RA. An evidence-based update on nonsteroidal anti-inflammatory drugs. Clin Med Res. 2007;5(1):19-34.

36. Maggini S, Wintergerst ES, Beveridge S, Hornig DH. Selected vitamins and trace elements support immune function by strengthening epithelial barriers and cellular and humoral immune responses. Br J Nutr. 2007; 98 Suppl 1:S29-S35.

37. Wintergerst ES, Maggini S, Hornig DH. Contribution of selected vitamins and trace elements to immune function. Ann Nutr Metab. 2007;51(4):301-323.

38. Hirano T, Murakami M, Fukada T, Nishida K, Yamasaki S, Suzuki T. Roles of zinc and zinc signaling in immunity: zinc as an intracellular signaling molecule. Adv Immunol. 2008;97:149-176. 
39. Rall LC, Meydani SN. Vitamin B6 and immune competence. Nutr Rev. 1993;51(8):217-225.

40. Cheng CH, Chang SJ, Lee BJ, Lin KL, Huang YC. Vitamin B6 supplementation increases immune responses in critically ill patients. Eur $J$ Clin Nutr. 2006;60(10):1207-1213.
41. Azofeifa K, Angulo Y, Lomonte B. Ability of fucoidan to prevent muscle necrosis induced by snake venom myotoxins: comparison of high- and low-molecular weight fractions. Toxicon. 2008;51(3): 373-380.

\section{Publish your work in this journal}

Biologics: Targets \& Therapy is an international, peer-reviewed journal focusing on the patho-physiological rationale for and clinical application of Biologic agents in the management of autoimmune diseases, cancers or other pathologies where a molecular target can be identified. This journal is indexed on PubMed Central, CAS, EMBase, Scopus and the Elsevier Bibliographic databases. The manuscript management system is completely online and includes a very quick and fair peerreview system, which is all easy to use. Visit http://www.dovepress. com/testimonials.php to read real quotes from published authors. 